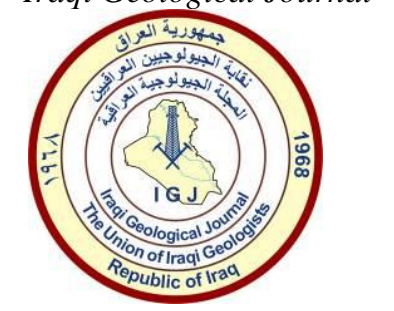

Iraqi Geological Journal

Journal homepage: https://www.igj-iraq.org

\title{
Hydrochemical Evaluation of Raw Water and Treated Water in the Liquefaction Plant of Kirkuk Unified Water Project Using WQI Technique, Northern Iraq
}

\author{
Ashty I. A. Al-Salihy ${ }^{1,}$, , Soran N. Sadeq ${ }^{1}$, Hassan A. A. Al-Jumaily ${ }^{1}$ \\ ${ }^{1}$ Department of Applied Geology, College of Science, University of Kirkuk, Kirkuk, Iraq \\ *Correspondence: ashtyibrahim@gmail.com
}

Received: 28 January 2021; Accepted: 18 March 2021; Published: 31 May 2021

\begin{abstract}
Potable water is one of the main sources for the sustainability and development of human life. The current study aimed to assess the hydrochemistry of water in the unified Kirkuk water project (as it supplies the neighborhoods of the city with drinking water) for the dry and wet season (2019-2020) and the efficiency of the plant in water purification. Eleven samples were collected for the dry and wet season (W1-W11) from raw water, before adding alum, after adding alum, sterilization basin, ground tanks and tap water. The major and minor elements $(\mathrm{Ca}+2$, $\mathrm{Mg}+2, \mathrm{Na}+, \mathrm{K}+, \mathrm{HCO} 3-, \mathrm{SO} 4-2, \mathrm{Cl}-, \mathrm{NO} 3-)$ were analyzed respectively. The chemical and physical properties are measured which include $\mathrm{pH}$, electrical conductivity, total dissolved solids (TDS), and turbidity. The results showed that they are in conformity with the specifications of the World Health Organization and the Iraqi Standard Specifications for the two seasons (dry and wet), except for the turbidity concentration in raw water for the two seasons, which was higher than the permissible limits due to weathering and erosion of geological layers as well as washing of agricultural lands and soils with rainwater. The application of the Water Quality Index indicated that the raw water samples were not suitable for drinking as they were classified under the category (unsuitable water), while the treated water samples were classified under the category (good water) for the dry and wet seasons.
\end{abstract}

Keywords: Kirkuk; Raw water; Treated water; Hydrochemistry

\section{Introduction}

Freshwater is one of the main natural resources for the survival and development of living organisms (Jiang et al., 2020) and plays an inevitable role in the development of various sectors of the economy, including agriculture, livestock production, forestry, industrial electricity generation, fisheries and other innovative sectors (Benjad and Olyaie, 2011), however, its importance lies primarily with human life, as it is considered a source of drinking water and due to its importance there is a need to conduct a hydro-chemical study of water in water treatment plants as it, directly and indirectly, affects human health, to provide water of good quality. Therefore, periodic assessment of the quality of drinking water sources is necessary to ensure the quality and safety of water supplies for people (Ameen, 2019). The increase in the population and the expansion of economic activities in recent years have led to different uses of water, which leads to deterioration in water quality (Varol et al., 2010; Al-Janabi et al., 2011).

DOI: $\underline{10.46717 / \text { igj.54.1E.7Ms-2021-05-28 }}$ 
Therefore, chemical reactions that occur between water and rocks as a result of weathering processes and environmental influences resulting from human activities such as industrial, agricultural and civil processes are among the factors that directly affect the quality of drinking water, as well as their effect on the quality of the water source and treatment processes inside the plants before pumping it to consumers (Abdul Hameed et al., 2010; Sánchez et al., 2017). The concept of water quality index (WQI) to illustrate water quality was first proposed by Horten (1965), as it is an important technique for assessing water quality and suitability for drinking purposes (Khudair and Al-Musawi, 2018; Awadh et al., 2016). It is defined as a mathematical equation that classifies water based on the most physiochemical properties affecting water quality (Fatah et al., 2020). Therefore, WQI is one of the most powerful tools for exploring, evaluating and managing water quality (Ramakrishnaiah et al., 2009). The current study aims to evaluate the hydro-chemical of raw and treated water in the unified Kirkuk water project using WQI.

\section{Materials and Methods}

\subsection{Study Area}

The unified Kirkuk water project is located in the northwestern part of Kirkuk longitude ( $\left.35^{\circ} 28^{\prime} 00^{\prime \prime}\right)$

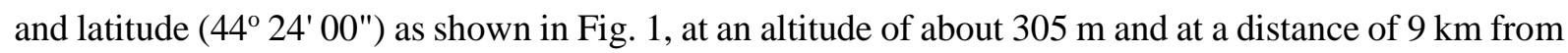
the city center, the coordinates of the sample's sites were recorded by Global Position System (GPS), (Table 1). The raw water samples were taken from the Lower Zab river and treated water from units of the Kirkuk unified water project, and tap water. The project has been designed with a production capacity of about $75,000 \mathrm{~m}^{3} / \mathrm{h}$ as it supplies most of the neighborhoods of Kirkuk and its surrounding areas with prepared drinking water. The project consists of several units in which raw water is treated (Fig. 1).

\subsubsection{Low lift pumping station}

This station is located $1 \mathrm{~km}$ from the project, in which raw water is drawn from the Kirkuk irrigation canal, and it consists of units:

- Suction basin

- Water enters it through gravity, it is $10 \mathrm{~m}$ long, $20 \mathrm{~m}$ wide, and $20 \mathrm{~m}$ deep.

- Low lift pump

- These pumps raise the raw water from the suction basin by hydraulic power, and it consists of 8 pumps arranged in two parallel sections. Each section consists of 4 pumps that work continuously, one of which is the reserve, and the drainage capacity of each pump is about $2700 \mathrm{~m} 3 / \mathrm{h}$.

\subsubsection{Water treatment plant}

It consists of the following units:

- Receiving basin.

- Flash mixture basins: It consists of 4 basins for the rapid mixing of water.

- Sedimentation Basins: This unit consists of 16 circular basins divided into 4 groups.

- Sand filters basin: This unit consists of 80 basins for rectangular sand filters, to which water enters through (20) lines of pipes.

- Sterilization unit: Chlorine is added at this stage to the water due to its great ability to interact with any harmful substances.

- Ground tanks: It consists of two underground tanks, each with a capacity of $16000 \mathrm{~m} 3$. 
- High lift pumping: In this unit, the prepared drinking water is pushed from the main tank to the city tanks.

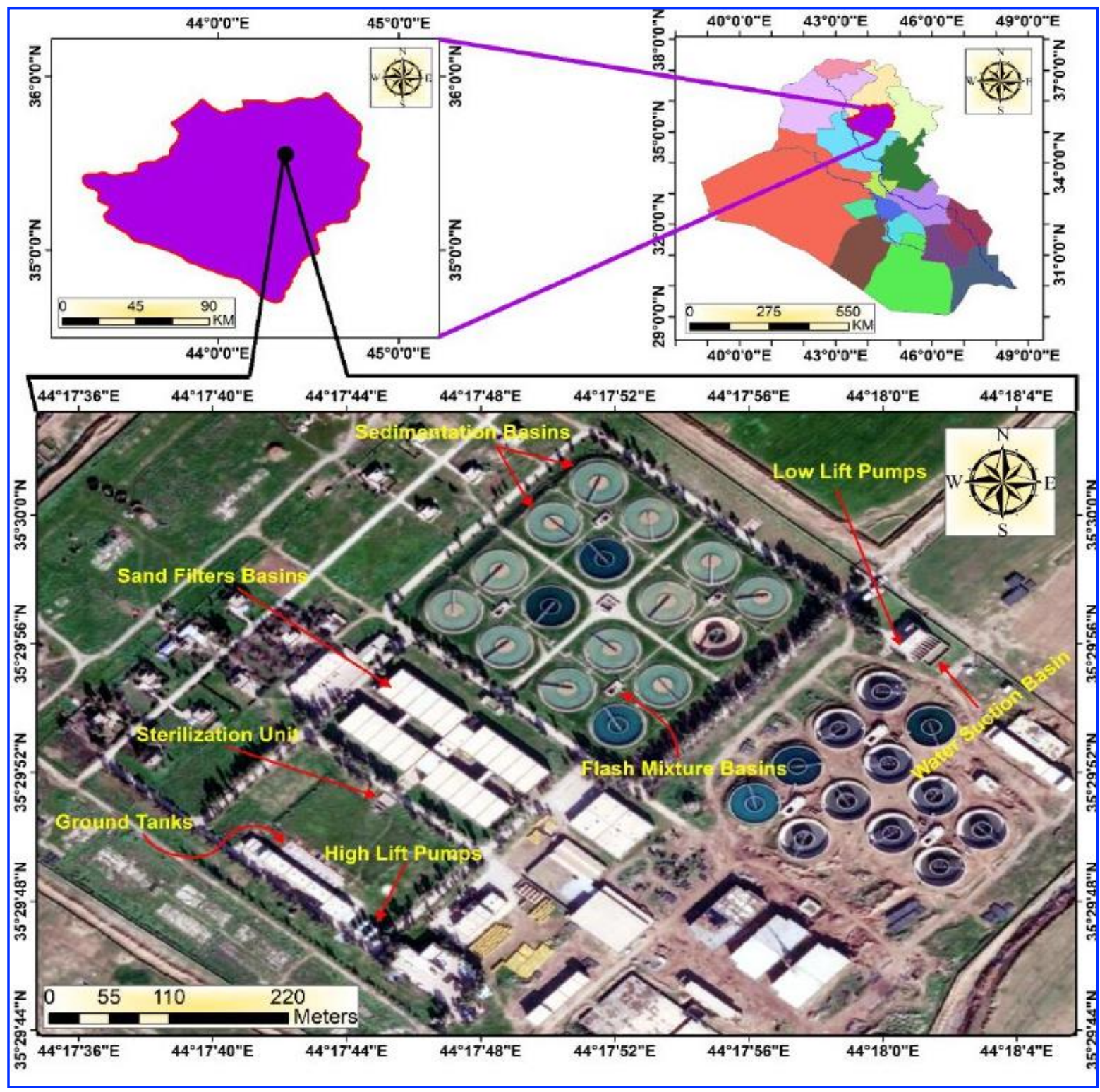

Fig.1. Location of study area and the station units (Arc GIS)

\subsection{Samples Preparation}

Eleven samples were collected from raw water (4), before adding alum (1), after adding alum (1), sterilization basin (1), underground tanks (1), tap water (3)), for the dry and wet seasons. And put it in high-density polyethylene bottles with a capacity of (1 liter). The bottles were washed several times with anionic water and then with sample water before use. And send it to the laboratories of the unified Kirkuk Water Directorate to measure some physical and chemical characteristics, which include the acidity function ( $\mathrm{pH}$ meter, WTW $\mathrm{pH}, 729$ ), electrical conductivity, total dissolved solids, and turbidity (HANNA-HH991300), and the analysis of the main positive, negative and minor elements, respectively, $\left(\mathrm{Ca}^{+2}, \mathrm{Mg}^{+2}, \mathrm{~K}^{+}, \mathrm{Na}^{+}, \mathrm{HCO}_{3}^{-}, \mathrm{SO}_{4}^{-2}, \mathrm{Cl}^{-}, \mathrm{NO}_{3}^{-}\right)$ 
Table 1. Coordinates and symbols and location of water samples

\begin{tabular}{|c|c|c|c|c|c|c|}
\hline \multicolumn{3}{|c|}{ Samples } & \multicolumn{4}{|c|}{ Location } \\
\hline Number & Water type & Location & $\mathrm{L}$ & & Lo & \\
\hline $\mathrm{W}_{1}$ & Raw Water & Dibis dam & $44^{\circ} 06^{\prime}$ & $43 " \mathrm{E}$ & $35^{\circ} 41^{\prime}$ & $14 " \mathrm{~N}$ \\
\hline $\mathrm{W}_{2}$ & Raw Water & Inside the canal in the city of Dibis & $44^{\circ} 04^{\prime}$ & $53 " \mathrm{E}$ & $35^{\circ} 39^{\prime}$ & $37 " \mathrm{~N}$ \\
\hline $\mathrm{W}_{3}$ & Raw Water & Near Basin 9/Lower zab river & $44^{\circ} 17^{\prime}$ & $52 " \mathrm{E}$ & $35^{\circ} 29^{\prime}$ & $57 " \mathrm{~N}$ \\
\hline $\mathrm{W}_{4}$ & Raw Water & Near K1 road/ Lower zab river & $44^{\circ} 18^{\prime}$ & $21 " \mathrm{E}$ & $35^{\circ} 30^{\prime}$ & $28 " \mathrm{~N}$ \\
\hline $\mathrm{W}_{5}$ & Raw Water & Before adding alum & $44^{\circ} 17^{\prime}$ & $52 " \mathrm{E}$ & $35^{\circ} 29^{\prime}$ & $57 " \mathrm{~N}$ \\
\hline $\mathrm{W}_{6}$ & Raw Water & After adding alum & $44^{\circ} 17^{\prime}$ & $52 " \mathrm{E}$ & $35^{\circ} 29^{\prime}$ & $57 " \mathrm{~N}$ \\
\hline W7 & Treated Water & Sterilization Unite & $44^{\circ} 17^{\prime}$ & $45 " \mathrm{E}$ & $35^{\circ} 29^{\prime}$ & $51 " \mathrm{~N}$ \\
\hline W8 & Treated Water & Ground tanks & $44^{\circ} 17^{\prime}$ & $43^{\prime \prime} \mathrm{E}$ & $35^{\circ} 29^{\prime}$ & $48 " \mathrm{~N}$ \\
\hline W9 & Treated Water & Tap water (Iskan area) & $44^{\circ} 22^{\prime}$ & $30 " \mathrm{E}$ & $35^{\circ} 28^{\prime}$ & $26 " \mathrm{~N}$ \\
\hline W10 & Treated Water & Tap water (Baghdad road area) & $44^{\circ} 22^{\prime}$ & $33 " \mathrm{E}$ & $35^{\circ} 25^{\prime}$ & $46 " \mathrm{~N}$ \\
\hline W11 & Treated Water & Tap water (Azadi area) & $44^{\circ} 24^{\prime}$ & $42 " \mathrm{E}$ & $35^{\circ} 28^{\prime}$ & $27 " \mathrm{~N}$ \\
\hline
\end{tabular}

*Water samples were taken for the dry and wet seasons at the same sites.

\subsection{Water Quality Index (WQI)}

The Water Quality Index (WQI) is expressed in numerical form, depending on several physiochemical characteristics most influenced by determining water quality (Singh et al., 2013) (Table 2). The Water Quality Index (WQI) is calculated by using the equation by Brown et al., (1972):

$$
\begin{array}{r}
\mathrm{Wi}=\frac{K}{\mathrm{Si}}, \ldots \ldots(1) \\
\mathrm{K}=\frac{1}{\sum_{i=1}^{n} \frac{1}{S i}}, \ldots \ldots(2) \\
\mathrm{Qi}=\left[\frac{V-V i}{S i-V i}\right] * 100, \ldots \ldots \\
\mathrm{WQI}=\frac{\sum_{\mathrm{i}=1}^{\mathrm{n}} \mathrm{WiQi}}{\sum_{\mathrm{i}=1}^{\mathrm{n}} \mathrm{Wi}}, \ldots \ldots
\end{array}
$$

Wi: Relative weight of physical and chemical parameters of water, K: constant value, Si: the standard value of the standards, V: the computed value (measured value), table (4) and (5). Vi: the ideal value (considered zero for all parameters except for $\mathrm{pH}=7$ ), Qi: a sub-standard indicator.

Table 2. The standard values ( $\mathrm{Si}$ ) and relative weights (Wi) of the physio-chemical parameters

\begin{tabular}{ccccc}
\hline Physicochemical parameters & $\mathrm{Si}(\mathrm{WHO}, 2017)$ & $1 / \mathrm{Si}$ & $\mathrm{K}$ & $\mathrm{Wi}$ \\
\hline $\mathrm{PH}$ & 8.5 & 0.118 & & 0.26 \\
$\mathrm{TDS}$ & 1000 & 0.001 & & 0.002 \\
Turbidity & 5 & 0.2 & & 0.442 \\
$\mathrm{Ca}^{+2}$ & 100 & 0.01 & & 0.022 \\
$\mathrm{Mg}^{+2}$ & 125 & 0.008 & & 0.018 \\
$\mathrm{Na}^{+}$ & 200 & 0.005 & 2.20751 & 0.011 \\
$\mathrm{~K}^{+}$ & 12 & 0.083 & & 0.184 \\
$\mathrm{SO}_{4}^{-2}$ & 250 & 0.004 & & 0.009 \\
$\mathrm{Cl}^{-}$ & 250 & 0.004 & & 0.009 \\
$\mathrm{NO}_{3}$ & 50 & 0.02 & & 0.044 \\
$\mathrm{Total}^{-}$ & & 0.453 & & 1 \\
\hline
\end{tabular}


Table 3. WQI values and water quality classification (Brown et al., 1972)

\begin{tabular}{lc}
\hline WQI & Water Type \\
\hline$<25$ & Excellent \\
$26-50$ & Good water \\
$51-75$ & Poor water \\
$76-100$ & Very poor water \\
$>100$ & Unsuitable water \\
\hline
\end{tabular}

\section{Results and Discussion}

\subsection{Physiochemical Parameters of Water}

The physiochemical properties of water are considered one of the basic and important factors in determining the quality of water, which includes laboratory and field measurements as follows:

\subsection{1. $\mathrm{pH}$}

The acidic function is a measure of the hydrogen ion concentration in aqueous solution (Rahmanian et al., 2015). The average concentration of $\mathrm{pH}$ for the dry and wet seasons (7.33) and (7.32), respectively (Table 4), and it was within the Iraqi standard specifications (IQS, 2009) and the World Health Organization (WHO, 2017).

\subsubsection{Electrical conductivity (EC).}

Is a measure of the ability of water to pass an electrical current, and is measured in units $(\mu / \mathrm{cm}$, or Mohs) (Eyankware, 2019). The average concentration of EC for the dry and wet seasons $(355.9 \mu \mathrm{s} / \mathrm{cm})$ and $(367.27 \mu \mathrm{s} / \mathrm{cm})$, respectively (Table 4$)$, The results showed an increase in the electrical conductivity values of the wet season compared with the dry season in all water samples due to the influence of the nature of the different sources that could be thrown into the river water in addition to the geological situation of the area (Kannah et al., 2018).

Table 4. Physical- chemical parameters of water samples in dry and wet season

\begin{tabular}{|c|c|c|c|c|c|c|c|c|}
\hline \multirow[t]{2}{*}{ Numbers } & \multicolumn{2}{|c|}{ pH } & \multicolumn{2}{|c|}{ Ec $(\mu \mathrm{s} / \mathrm{cm})$} & \multicolumn{2}{|c|}{ TDS (ppm) } & \multicolumn{2}{|c|}{ Turbidity (NTU) } \\
\hline & D.S & W.S & D. $\mathbf{S}$ & W.S & D.S & W.S & D.S & W.S \\
\hline $\mathrm{W}_{1}$ & 7.4 & 7.6 & 357 & 355 & 286 & 320 & 16 & 36 \\
\hline $\mathrm{W}_{2}$ & 7.5 & 7.2 & 342 & 366 & 268 & 332 & 20 & 44 \\
\hline $\mathrm{W}_{3}$ & 7.4 & 7.4 & 350 & 366 & 294 & 324 & 25 & 54 \\
\hline $\mathrm{W}_{4}$ & 7.4 & 7.2 & 355 & 367 & 290 & 335 & 23 & 55 \\
\hline $\mathrm{W}_{5}$ & 7.4 & 7.4 & 354 & 367 & 294 & 329 & 20 & 58 \\
\hline $\mathrm{W}_{6}$ & 7.3 & 7.5 & 353 & 368 & 286 & 310 & 14 & 10 \\
\hline $\mathrm{W}_{7}$ & 7.2 & 7.4 & 356 & 368 & 288 & 315 & 5 & 4 \\
\hline $\mathrm{W}_{8}$ & 7.4 & 7.1 & 359 & 370 & 292 & 268 & 4.6 & 4 \\
\hline $\mathrm{W}_{9}$ & 7.2 & 7.4 & 360 & 376 & 288 & 254 & 3.7 & 5 \\
\hline $\mathrm{W}_{10}$ & 7.2 & 7.2 & 366 & 368 & 296 & 267 & 4 & 4.2 \\
\hline $\mathrm{W}_{11}$ & 7.3 & 7.2 & 363 & 369 & 288 & 254 & 3.2 & 4.9 \\
\hline Range & $7.2-7.5$ & 7.1-7.6 & $342-363$ & $355-376$ & $268-296$ & $254-335$ & $3.2-25$ & $4-58$ \\
\hline Average & 7.33 & 7.32 & 355.9 & 367.27 & 288.18 & 300.72 & 12.59 & 25.37 \\
\hline (IQS, 2009) & \multicolumn{2}{|c|}{$6.5-8.5$} & \multicolumn{2}{|c|}{2000} & \multicolumn{2}{|c|}{1000} & \multicolumn{2}{|c|}{5} \\
\hline (WHO, 2017) & \multicolumn{2}{|c|}{$6.5-8.5$} & \multicolumn{2}{|c|}{$\ldots$} & \multicolumn{2}{|c|}{1000} & \multicolumn{2}{|c|}{5} \\
\hline
\end{tabular}

*D. S: - refers to the dry season. *W. S: - refers to the wet season. 


\subsubsection{Total dissolved solids (TDS)}

It includes all the remaining materials resulting from water evaporation, (WHO, 2017). The average concentration of TDS for the dry and wet seasons $(288.18 \mathrm{ppm})$ and $(300.72 \mathrm{ppm})$, respectively (Table 4 ), The results showed an increase in its concentrations in water samples in the wet season compared to the dry season due to the weathering and erosion processes that the geological structures that the river pass through (Al-Obaidy et al., 2015), and it was found to increase in the tap water samples in the dry and wet seasons due to the phenomenon of pipe corrosion (WHO, 2017).

\subsubsection{Turbidity}

It is a measure of the relative purity of water (Serajuddin et al., 2019), it is measured in the (NTU) Nephlometric Turbidity Unit. The average concentration of EC for the dry and wet seasons (12.59NTU) and (25.37 NTU), respectively (Table 4) The results showed that the concentrations of turbidity in raw water were higher than wet season compared to the dry season due to rainfalls and agricultural activities (Hassan and Al-Shamaa, 2018), while their concentration in the samples of treated water was less than raw water, which indicates the plant's good efficiency to removing turbidity.

\subsection{Chemical Analyses}

\subsubsection{Major cations}

\section{- Calcium ion $\left(\mathrm{Ca}^{+2}\right)$}

The average concentration of calcium for the dry and wet seasons (41.64ppm) and (39.84ppm), respectively (Table 5), The results showed that the calcium concentration increased in the dry season compared to the wet season in raw water samples due to the evaporation process that occurs as a result of high temperatures (Al-Obaidy et al., 2015).

- $\quad$ Magnesium ion $\left(\mathrm{Mg}^{+2}\right)$

The average concentration of magnesium for the dry and wet seasons (15.58 ppm) and (22.35 ppm), respectively (Table 5). The increase in the concentration of magnesium ion in the wet season relative to the dry season due to the rain factor is observed through washing of clay minerals and evaporation structures exposed along the river (Dinka et al., 2015), and their concentration in tap water for the two seasons was high compared to other samples due to corrosion of the pipes in distribution networks (Al-Obaidy et al. 2015).

\section{- $\quad$ Sodium ion $\left(\mathrm{Na}^{+}\right)$}

The average concentration of sodium for the dry and wet seasons $(6.93 \mathrm{ppm})$ and $(8.53 \mathrm{ppm})$, respectively (Table 5), The results showed a slight increase in the sodium concentration in the wet season compared to the dry season, as a result of washing sediments containing the element sodium through weathering of rock salts and ion exchange in clay minerals (Dinka et al., 2015; Awadh and Ahmed, 2013; Al-Harahshah et al., 2020).

- Potassium ion $\left(\mathrm{K}^{+}\right)$

The average concentration of potassium for the dry and wet seasons (1.13 ppm) and (1.72ppm), respectively (Table 5), The results of the study showed an increase in the concentration of potassium ion in water samples in the wet season relative to the dry season due to washing and weathering the minerals of $\mathrm{SiO}^{2}$ as a result of rain fall (Kannah et al., 2018) as well as the use of chemical fertilizers in agricultural lands that cause Increase its concentration in water.

Table 5. Ranges and averages of concentrations of the major elements (cations and anions) and minor elements of water samples for the dry and wet seasons in ppm 


\begin{tabular}{|c|c|c|c|c|c|c|c|c|c|}
\hline No. & Season & $\mathrm{Ca}^{2+}$ & $\mathrm{Mg}^{2+}$ & $\mathrm{Na}^{+}$ & $\overline{\mathbf{K}^{+}}$ & $\mathrm{HCO}_{3}{ }^{-}$ & $\mathrm{SO}^{2-}$ & $\mathrm{Cl}^{-}$ & $\mathrm{NO}_{3}{ }^{-}$ \\
\hline $\mathrm{W}_{1}$ & \multirow{12}{*}{$\begin{array}{l}\tilde{0} \\
\tilde{D} \\
\mathbb{D} \\
\infty \\
\vec{D}\end{array}$} & 44.2 & 17.2 & 6.65 & 1.56 & 152.28 & 29 & 22.6 & 0.5 \\
\hline $\mathrm{W}_{2}$ & & 38.6 & 14.8 & 6.94 & 0.96 & 144.28 & 29 & 15.2 & 0.4 \\
\hline $\mathrm{W}_{3}$ & & 40.2 & 14.6 & 7.01 & 0.58 & 146.5 & 29 & 15.1 & 0.3 \\
\hline $\mathrm{W}_{4}$ & & 39.6 & 14.4 & 6.75 & 0.69 & 140.28 & 31 & 15.8 & 0.5 \\
\hline $\mathrm{W}_{5}$ & & 46.2 & 17.1 & 7.15 & 1.65 & 151.06 & 31 & 24.2 & 0.4 \\
\hline $\mathrm{W}_{6}$ & & 38.6 & 14.3 & 7.1 & 0.84 & 142.28 & 29 & 14.8 & 0.3 \\
\hline $\mathrm{W}_{7}$ & & 39.6 & 14.2 & 7.2 & 0.88 & 141.06 & 29 & 15.2 & 0.2 \\
\hline $\mathrm{W}_{8}$ & & 42.8 & 16.8 & 6.66 & 1.48 & 151.06 & 29 & 22.6 & 1.98 \\
\hline $\mathrm{W}_{9}$ & & 44.2 & 16.8 & 7.13 & 1.44 & 152.28 & 29 & 22.8 & 0.3 \\
\hline $\mathrm{W}_{10}$ & & 44.5 & 17.2 & 6.7 & 1.72 & 154.72 & 29 & 24.1 & 0.3 \\
\hline $\mathrm{W}_{11}$ & & 46.4 & 16.6 & 6.83 & 1.61 & 153.5 & 29 & 22.4 & 2.6 \\
\hline Range & & $37.6-46.4$ & $14.2-17.2$ & $6.66-7.2$ & $0.58-1.65$ & $140.28-153.5$ & $29-31$ & $14.8-24.2$ & $0.2-1.98$ \\
\hline Average & \multirow{16}{*}{ 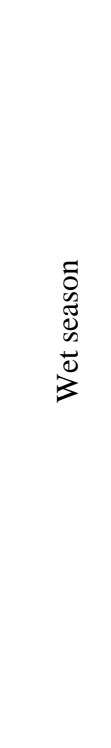 } & 41.64 & 15.58 & 6.93 & 1.13 & 146.37 & 29.55 & 18.8 & 1.1 \\
\hline $\mathrm{W}_{1}$ & & 40.4 & 25.3 & 8.65 & 2.06 & 175.4 & 33 & 28.6 & 2.1 \\
\hline $\mathrm{W}_{2}$ & & 37.3 & 17.6 & 9.02 & 1.46 & 140.28 & 35 & 20.8 & 1.6 \\
\hline $\mathrm{W}_{3}$ & & 39.1 & 17.9 & 9.11 & 1.08 & 155.28 & 32 & 21.2 & 1.2 \\
\hline $\mathrm{W}_{4}$ & & 37.1 & 18.8 & 8.78 & 1.19 & 145.28 & 33 & 22.4 & 1.9 \\
\hline $\mathrm{W}_{5}$ & & 42.4 & 25.2 & 9.3 & 2.15 & 180.28 & 35 & 30.4 & 1.6 \\
\hline $\mathrm{W}_{6}$ & & 36.9 & 20.2 & 9.23 & 1.34 & 160.72 & 30 & 21.3 & 1.2 \\
\hline $\mathrm{W}_{7}$ & & 38.1 & 19.6 & 9.36 & 1.38 & 150.5 & 32 & 25.6 & 0.8 \\
\hline $\mathrm{W}_{8}$ & & 41.7 & 22.7 & 8.66 & 1.98 & 180.28 & 30 & 20.3 & 3.8 \\
\hline $\mathrm{W}_{9}$ & & 41.8 & 25.5 & 7.34 & 1.94 & 183.94 & 30 & 21.2 & 1.2 \\
\hline $\mathrm{W}_{10}$ & & 42.3 & 26.1 & 7.03 & 2.11 & 180.5 & 31 & 20.8 & 3.1 \\
\hline $\mathrm{W}_{11}$ & & 41.1 & 26.9 & 7.34 & 2.22 & 183.94 & 31 & 21.7 & 1.2 \\
\hline Range & & $36.9-42.4$ & $17.6-26.9$ & $7.03-9.36$ & $1.08-2.22$ & $145.28-183.94$ & $30-35$ & $20.3-30.4$ & $0.8-3.8$ \\
\hline Average & & 39.84 & 22.35 & 8.53 & 1.72 & 166.95 & 32 & 23.12 & 1.79 \\
\hline $\begin{array}{l}\text { (IQS, } \\
2009)\end{array}$ & & 50 & 50 & 200 & 12 & $\ldots$ & 250 & 250 & 50 \\
\hline $\begin{array}{c}\text { (WHO, } \\
2017)\end{array}$ & & 100 & 125 & 200 & $\ldots$ & $\ldots$ & 250 & 250 & 50 \\
\hline
\end{tabular}

\subsubsection{Major anions}

- $\quad$ Bicarbonate ion $\left(\mathrm{HCO}_{3}^{-2}\right)$.

The average concentration of bicarbonate for the dry and wet seasons (146.37ppm) and (166.95ppm), respectively (Table 5), The high concentration of bicarbonate was observed in the wet season as a result of the high-water level, which caused the weathering and dissolving of carbonate rocks (limestone, dolomite, magnesite) and their discharges into the water along the river (Al-Obaidy et al., 2015; Dinka et al., 2015; Fayydh et al., 2020).

- $\quad$ Sulphate $\left(\mathrm{SO}_{4}^{-2}\right)$.

The average concentration of sulphate for the dry and wet seasons (29.55 ppm) and (32 ppm), respectively (Table 5), The results showed a slight increase in the concentration of sulfate ion in the wet season of raw water samples due to the high water level during the period of water increase, thus increasing the chance of weathering of sedimentary rocks (gypsum and anhydrite) exposed in the study area, which is a major source of sulfate in the water (Donkor et al., 2018), as well as the use of chemical fertilizers containing sulfates on agricultural lands (Awadh and Ahmed, 2012).

- Chloride ion $\left(\mathrm{Cl}^{-1}\right)$.

The average concentration of chloride for the dry and wet seasons (18.8 ppm) and (23.12ppm), respectively (Table 5) The results showed an increase in the concentration of chlorine ion in the dry season of treated water samples compared to raw water samples due to the dissolution of lime present on the pipes carrying water in the distribution networks systems (Al-Obaidy et al., 2015), as well as the chlorine added to the water after the filtration process to sterilize the water and oxidize a number of contaminated compounds in treated water. 


\subsubsection{Minor ions}

- $\quad$ Nitrates ion $\left(\mathrm{NO}_{3}^{-}\right)$

The average concentration of nitrates for the dry and wet seasons (1.1ppm) and (1.79ppm), respectively (Table 5). An increase in the concentration of nitrates was observed in the wet season compared to the dry season due to the high level of water and the washing of sediments from agricultural lands through using fertilizers and discharging them into the feeding channel of the project, as well as the decomposition of plants in the water into ammonia by living organisms and then into nitrite and nitrates (Hassan and Al-Shamaa, 2018).

\subsection{Water Quality Index (WQI)}

The Water Quality Index (WQI) is an important measurement used to determine the quality of water and its suitability for drinking purposes (Fernández et al., 2004), by comparing it with the standards recommended by the WHO. Monitoring drinking water quality is one of the environmental activities by developing water management, treatment, and distribution plans to maintain drinking water supply systems (Awadh et al., 2016). The results showed that the water quality index of all raw water samples for the dry and wet seasons was WQI $>100$, and it was within the Unsuitable water type, while its value in the all treated water samples was WQI > 50, and it was within the good water type (Table 6).

Table 6. WQI values for water samples and for two seasons (dry-wet) in the study area

\begin{tabular}{ccc}
\hline \multicolumn{3}{c}{ Water Quality Index } \\
\hline Samples No. & Dry Season & Wet Season \\
$\mathrm{W}_{1}$ & 146.44 & 324.65 \\
$\mathrm{~W}_{2}$ & 180.95 & 392.92 \\
$\mathrm{~W}_{3}$ & 224.25 & 481.25 \\
$\mathrm{~W}_{4}$ & 206.77 & 490.89 \\
$\mathrm{~W}_{5}$ & 181.96 & 518.47 \\
$\mathrm{~W}_{6}$ & 127.17 & 93.39 \\
$\mathrm{~W}_{7}$ & 47.46 & 39.87 \\
$\mathrm{~W}_{8}$ & 45.45 & 40.52 \\
$\mathrm{~W}_{9}$ & 37.02 & 49.4 \\
$\mathrm{~W}_{10}$ & 40.11 & 42.79 \\
$\mathrm{~W}_{11}$ & 32.72 & 49.02 \\
Average & 115.48 & 247.41 \\
\hline
\end{tabular}

\section{Conclusions}

The aim of any water purification plant is to produce safe, drinkable, and palatable water for consumers. In this study, the hydrochemical evaluation of water was evaluated in the unified Kirkuk water project as it supplies most of the living creatures with water, It was found that most of the physio-chemical parameters of the studied samples were within the recommended limits according to the standards of the WHO and the Iraqi standard specifications (IQS), except for the concentration of turbidity in the raw water of the samples for the dry and wet seasons, they were recorded higher than the permissible limits, while their concentration decreased in the treated water and for both seasons, which indicates the good efficiency of the plant in removing turbidity. By applying the water quality index for both seasons depending on the elements and physiochemical properties most influencing water quality, the results showed that the raw water samples for the two seasons were WQI $>100$ which indicates their inadequacy for drinking and is classified under the category (Unsuitable water). The treatment recorded WQI $<50$ indicating that it is potable water and was classified under the category of good water. Through some observations of the results, it is recommended to conduct periodic checks to monitor the 
water quality of the Lower Zab River and to maintain its quality, and to conduct bacteriological checks of the water, in addition to providing units for measuring toxic elements, as the station is located within an oil industry area, which emits toxic industrial waste with heavy elements.

\section{Acknowledgements}

The authors are very grateful to the Editor in Chief Prof. Dr. Salih M. Awadh, the Secretary of Journal Mr. Samir, R. Hijab and the Technical Editors for their great efforts and valuable comments.

\section{References}

Abdul Hameed, M. J., A., Haider, S. A., Bahram, K. M., 2010. Application of water quality index for assessment of Dokan lake ecosystem, Kurdistan region, Iraq. Journal of Water Resource and protection, 2, 792-798.

Al-Harahsheh, S. T., Al-Raggad, M., Al-Shdaifat, A., Al-Wreikat, M., 2020. Hydrochemical evaluation of the azraq unconfined aquifer, Jordan. Iraqi Geological Journal, 53 (2A), 1-18.

Al-Janabi, K. W. S., Alazawi, F. N., Mohammed, M. I., Kadhum, A. A. H., Mohamad, A. B., 2011. Chlorophenols in Tigris River and drinking water of Baghdad, Iraq. Bulletin of environmental contamination and toxicology, 87(2), 106-112.

Al-Obaidy, A. H. M., Al-Janabi, Z. Z., Shakir, E., 2015. Assessment of water quality of Tigris River within Baghdad City. Mesopotamia Environmental Journal, 1(3), 90-98.

Ameen, H. A., Rekani, O. A., Barwari, V. I., 2019. Application of pollution indices for heavy metal contamination assessment in surface water of Duhok Dam (Kurdistan Region, Iraq). Journal of Duhok University, 22(1), 252-264.

Asare-Donkor, N. K., Ofosu, J.O., and Adimado, A. A., 2018. Hydrochemical characteristics of surface water and ecological risk assessment of sediments from settlements within the Birim River basin in Ghana. Environmental Systems Research, 7(1), 9.

Awadh, S. M., Ahmed, R. M., 2013. Hydrochemistry and pollution probability of selected sites along the Euphrates River, Western Iraq. Arabian Journal of geosciences, 6(7), 2501-2518.

Awadh, S. M., Al-Kilabi, J. A., Abdulhussein, F. M., 2016. Assessment of groundwater quality using water quality indexin, Al-Hawija area, northern Iraq. Iraqi Geological Journal, 67-76.

Banejad, H., Olyaie, E., 2011. Application of an artificial neural network model to rivers water quality indexes prediction-a case study. Journal of American science, 7(1), 60-65.

Brown, R. M., McClelland, N.I., Deininger, R. A., O’Connor, M. F., 1972. A water quality index crashing the psychological barrier. In Indicators of environmental quality, 173-182.

Dinka, M. O., Loiskandl, W., Ndambuki, J. M., 2015.Hydrochemical characterization of various surface water and groundwater resources available in Matahara areas, Fantalle Woreda of Oromiya region. Journal of Hydrology: Regional Studies, 3, 444-456.

Eyankware, M. O., 2019. Hydrogeochemical Assessment of Chemical Composition of Groundwater; A Case Study of the Aptian-Albian Aquifer within Sedimentary Basin (Nigeria). Water Conservation and Management, 3(1), 01-07.

Fatah, K. K., Hamed, M., Saeed, M. H., Dara, R., 2020. Evaluation groundwater quality by using GIS and water quality index techniques for wells in Bardarash area, Northern Iraq. Iraqi Geological Journal, 53, 87-104.

Fayydh, A. M., Zaidan, T. A., Al-Heety, E. A., 2020. Evaluation of groundwater quality in al-waffa and kubaysa areas using multivariate statistical analysis, Al-anbar, Western Iraq. Iraqi Geological Journal, 53 (2D), 107-127.

Fernández, N., Ramírez, A. and Solano, F., 2004. Physico-chemical water quality indices-a comparative review. Bistua: Revista de la Facultad de CienciasBásicas, 2(1), 19-30.

Hassan, M. I., Al Shamaa, A. M., 2018. Some water properties and suitability of Shatt Al-Hilla in Babil Governorate, Iraq. Journal of University of Babylon for Pure and Applied Sciences, 26(9), 129-13.

Horton, R. K., 1965. An index number system for rating water quality. Journal Water Pollution Control Fed, 37(3), 300-306.

Iraqi Standar., 2009.Iraq Standar of Drinking Water No.417, Second Modification. 
Jiang, Y., Gui, H., Yu, H., Wang, M., Fang, H., Wang, C., Chen, C., Zhang, Y., Huang, Y., 2020. Hydrochemical characteristics and water quality evaluation of rivers in different regions of cities: a case study of Suzhou City in Northern Anhui Province, China. Water, 12(4), 950.

Kannah, A. M. A., Al-Jubouri, M. I., Aumary, A.W., 2018. Comparison between some water characters of the Lesser Zap with anImpoundment Ground Water Close to it. Journal of Mosul Studies, 212-222.

Khudair, B.H., and Al-Musawi, N. O., 2018. Water quality assessment and total dissolved solids prediction using artificial neural network in Al-Hawizeh Marsh South of Iraq. Journal of Engineering, 24(4), 147-156.

Rahmanian, N., Ali, S. H. B., Homayoonfard, M., Ali, N. J., Rehan, M., Sadef, Y. and Nizami, A. S., 2015. Analysis of physiochemical parameters to evaluate the drinking water quality in the state of Perak, Malaysia. Journal of Chemistry, 10.

Ramakrishnaiah, C. R., Sadashivaiah, C., Ranganna, G., 2009. Assessment of water quality index for the groundwater in Tumkur Taluk, Karnataka State, Indian Journal of Chemistry, 6(2), 523-530.

Sánchez, E. R. S., Hoyos, S. E. G., Esteller, M.V., Morales, M. M., Astudillo, A. O., 2017. Hydrogeochemistry and water-rock interactions in the urban area of Puebla Valley aquifer (Mexico). Journal of Geochemical Exploration, 181, 219-235.

Serajuddin, M., Chowdhury, M. A., Haque, M. M., Haque, M. E., 2019. Using turbidity to determine total suspended solids in an urban stream: a case study. In Proceedings of the 2nd International Conference on Water and Environmental Engineering, Dhaka, 19-22.

Singh, A. K., Raj, B., Tiwari, A. K., Mahato, M. K., 2013. Evaluation of hydrogeochemical processes and groundwater quality in the Jhansi district of Bundelkhand region, Indiaian Environmental Earth Sciences, 70(3), 1225-1247.

Varol, M., Gökot, B. and Bekleyen, A., 2010. Assesment of water pollution in the Tigris River in Diyarbakır, Turkey. Water Practice and Technology, 5(1).

World Health Organization, 2017. Guidelines for drinking-water quality: incorporating first addendum. 